\title{
ОСОБЛИВОСТІ ВИКЛАДАННЯ КУРСУ НЕОНАТОЛОГІЇ СТУДЕНТАМ АНГЛОМОВНОЇ ФОРМИ НАВЧАННЯ
}

\author{
В. В. Моцар, I. А. Трофімова \\ ДУ “Кримський державний медичний університет імені С. І. Георгієвського”
}

\section{PECULIARITIES OF TEACHING OF NEONATOLOGY FOR ENGLISH- LANGUAGE STUDENTS}

\author{
V. V. Motsar, I. A. Trofimova \\ SE "Crimean State Medical University by S. I. Heorhiyevskyi”
}

\begin{abstract}
3 метою оптимізаціі навчального процесу при вивченні неонатології на 5 курсі у студентів англомовної форми навчання на кафедрі педіатрії з курсом дитячих інфекційних хвороб ДУ “Кримський державний медичний університет імені С. І. Георгісвського” проведений ряд методичних удосконалень. Методичні удосконалення впроваджені в процес проведення занять із студентами у вигляді методичних рекомендацій на паперових і електронних носіях. Трирічний досвід кафедри свідчить, що ця система дає можливість отримати англомовним студентам достатні знання 3 основних тем неонатології і покращує “виживаність” знань, що підтверджується результатами державного тестування КРОК-2.

With an aim of educational process optimization at the study of neonatology on the 5 course for the students of the Englishlanguage form of educating on the department of pediatrics with the course of child's infectious diseases of «Crimean State Medical University named after S. I. Heorhievskyi» the row of methodical improvements is conducted. Methodical improvements inculcated as in the process of realization of reading with students, nevertheless as methodical recommendations on a paper and electronic carrier. Three-year experience of department testifies that this system gives an opportunity to get to the Englishlanguage students sufficient knowledge on the basic themes of neonatology and improves "survivability" of knowledge, that confirmed by the results of the state testing KROK -2 .
\end{abstract}

Вступ. Неонатологія - розділ педіатрії, наука про виходжування новонароджених: вишукування оптимальних методів діагностики та лікування хвороб у дітей перших чотирьох тижнів життя, реабілітації хворих новонароджених, створення в неонатальному періоді умов, необхідних для формування стану здоров'я у всьому подальшому житті людини. В даний час відбувається бурхливий розвиток неонатології, зумовлений чітким усвідомленням факту провідної ролі перинатальних факторів в етіології і патогенезі багатьох хронічних хвороб людини [1].

Основна частина. Методика викладання неонатології в медичному вузі включає в себе дві складові: базову теоретичну підготовку та практичну частину. Дисбаланс між цими компонентами, як правило, призводить до погіршення рівня підготовки, зниження “виживання" знань, що надалі суттєво позначається на несвоєчасності та якості діагностики неонатальної патології, а отже, і результатах лікування. Найбільша складність у викладанні виникає при роботі з англомовними студентами.

Враховуючи вищесказане, на кафедрі педіатрії 3 курсом дитячих інфекційних хвороб Кримського дер- жавного медичного університету імені С. І. Георгієвського проведено ряд методичних удосконалень у розділі неонатології циклу дитячих хвороб. Методичні удосконалення складені і впроваджені відповідно до вимог Болонської системи навчання.

Мета навчання - оптимізація навчального процесу при вивченні неонатології на 5 курсі у студентів англомовної форми навчання.

Цикл неонатології розрахований на 4 години теоретичних, 25 практичних і 28 годин самостійної роботи. Кількість студентів в групі не перевищує 8. Заняття проводяться на кафедрі педіатрії з курсом дитячих інфекційних хвороб, розташованій на базі Кримської республіканської дитячої клінічної лікарні. Практичні заняття і самостійна робота студентів проходять в спеціалізованих відділеннях - патології новонароджених, недоношених новонароджених, реанімації новонароджених. Відділення обладнані сучасними діагностичними та лікувальними комплексами: кювезами для виходжування новонароджених та постійного моніторингу, пульсоксиметром "ЮТАСОКСІ-200", апаратом ШВЛ Servo-I та ін. Лекційний курс читається англійською мовою, матеріал ілюструється мультимедійними пре-

\footnotetext{
(C) В. В. Моцар, I. А. Трофімова
} 
зентаціями (рис. 1, 2). Для якісного засвоєння лекційного матеріалу студентам пропонується стандартизова- ний конспект, в якому роздруковані всі лекційні слайди 3 можливістю їх коментування (рис. 3).

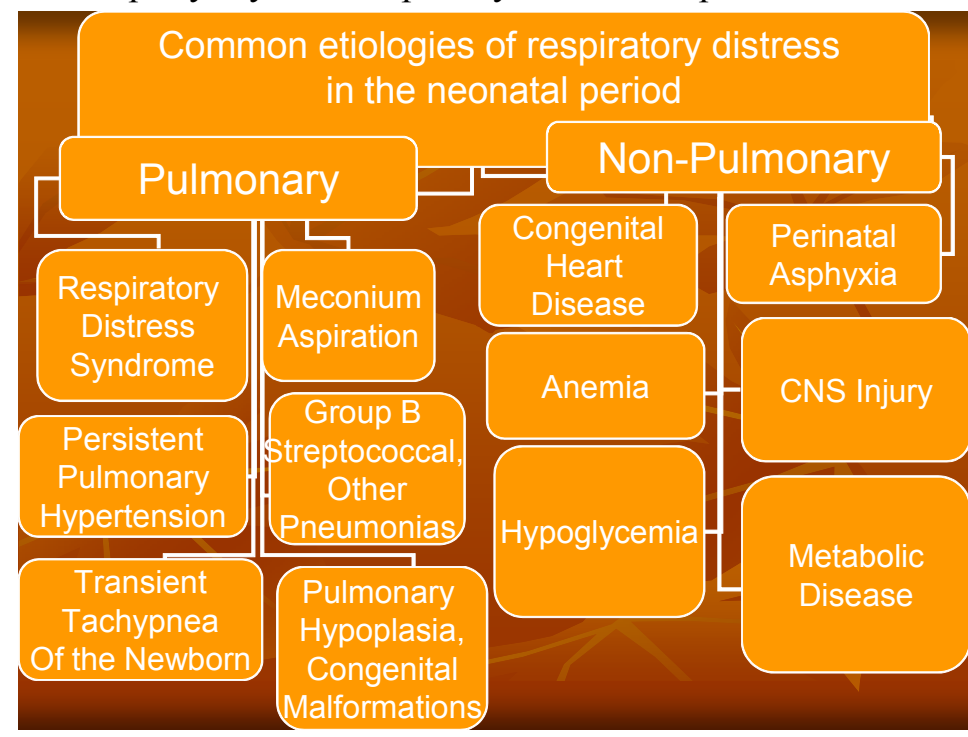

Puc. 1. Слайд ілюструє основні етіологічні фактори респіраторного дистрес-синдрому у

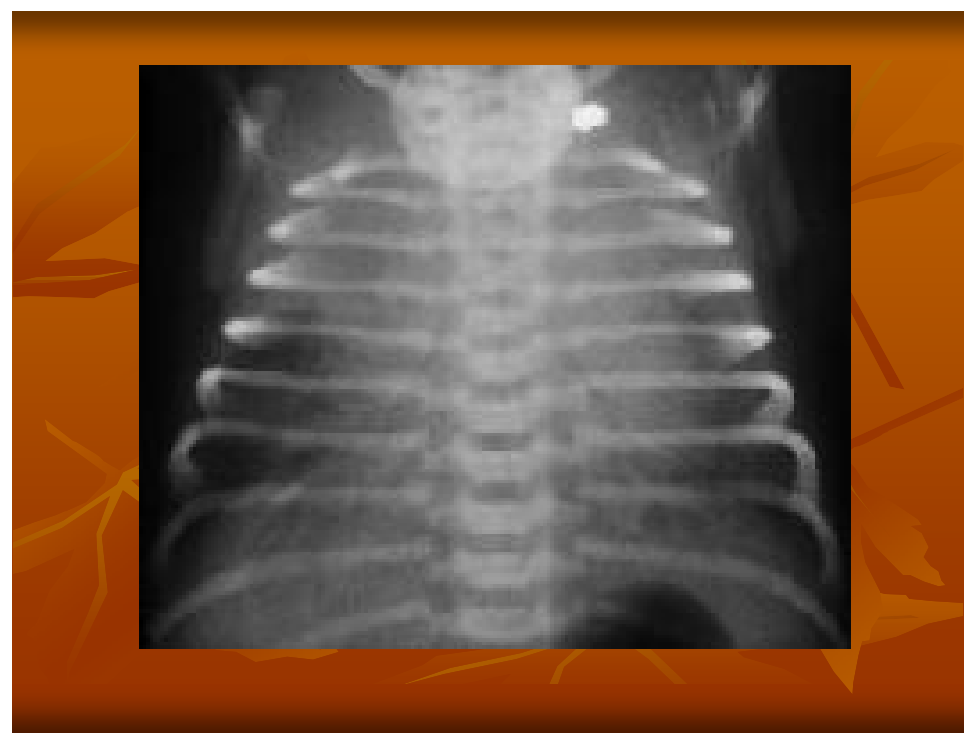
новонароджених.

Puc. 2. Слайд ілюструє рентгенологічну картину транзиторного тахіпное у новонародженого.

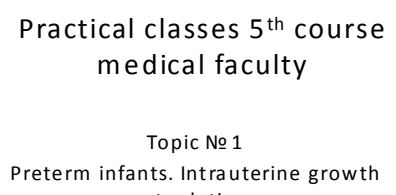

Puc. 3. Фрагмент стандартизованого конспекту лекцій.

Розділ неонатології включає п’ять практичних занять. Теми занять:

1. Недоношений новонароджений. Затримка внутрішньоутробного розвитку плода. (Preterm infants. Intrauterinegrowth retardation.)

2. Асфіксія плода та новонародженого. Пологові травми. (Asphyxia of fetus and newborn. Birth injuries.)
3. Гемолітична хвороба новонародженого. Геморагічна хвороба новонародженого. (Hemolytic disease of the newborn. Hemorrhagic disease of the newborn.)

4. Респіраторні розлади у новонароджених. (Respiratory disorders in newborns.)

5. Внутрішньоутробні інфекції. Неонатальний сепсис. (Intrauterine infections. Neonatal sepsis.) 
Практичне заняття складається 3 наступних розділів.

1. Обгрунтування актуальності теми, формулювання мети і завдань заняття.

2. Визначення вихідного рівня знань студента шляхом тестування на паперових носіях.

3. Курація хворих у профільних відділеннях, збір медичної інформації для історії хвороби.

4. Обговорення отриманої інформації з розбором хворих відповідно до теми заняття.

5. Оцінка кінцевого рівня знань у формі рішення ситуаційних завдань.

Практичні заняття в навчальній кімнаті проводяться англійською мовою, а в період курації викладач допомагає студентам спілкуватися 3 пацієнтами, переводячи на англійську мову важкозрозумілі фрагменти мови пацієнтів. Актуальність теми обгрунтовується частотою патологічних станів у дітей в періоді новонародженості і анатомо-фізіологічними особливостями дитячого організму, що є причиною виникнення і особливостями перебігу захворювань у цьому періоді життя. Мета ізавдання грунтуються на необхідності повноцінної діагностики у відносно короткий проміжок часу і виборі адекватної схеми лікування. Студент вирішує це завдання шляхом аналізу анамнестичних даних, показників об'єктивного дослідження хворого, клініко-біохімічних, функціональних, інструментальних та додаткових методів обстеження.

Особлива увага приділяється наступній медичній інформації та зв' язку навчального процесу з попередніми дисциплінами та кафедрами. 3 цією метою здійснюється тестовий контроль вихідного рівня знань. Тести віддруковані англійською мовою на паперових носіях. Тематика тестів узгоджена 3 кафедрами, які викладаються на попередніх курсах (патологічної анатомії, патологічної фізіології, фармакології, пропедевтики дитячих хвороб, терапіі). Аналіз вихідного рівня знань дозволяє оцінити ступінь їх виживання, результати доводяться до відома суміжних кафедр, що дозволяє в цілому сформувати у студентів цілісне уявлення про лікувально-діагностичний процес при неонатальній патології у дітей. Зразок тестового завдання для визначення вихідного рівня знань студента. Text question: What is the period of fetal exposure is blastogenesis? (Який період внутрішньоутробного розвитку плода називається бластогенез?)

1. Answer From the moment of impregnation - to 15 day ( з моменту імпрегнації до 15 дня).

2. Answer From 5 day of impregnation - to 20 day ( 3 5-го дня імпрегнації до 20-го дня).

3. Answer From 16-30 day after impregnation (3 1630 дня після імпрегнаціi).

4. Answer 40-78 day of intrauterine life (40-78 день внутрішньоутробного життя).

5. Answer From 78 day - to birth ( 78 дня до народження).

Опанування та застосування необхідних практичних навичок $є$ серйозною проблемою для англомовних студентів. Багато в чому це пов'язано 3 подоланням мовного бар'єра. Тому основна увага приділяється курації пацієнтів. Курація здійснюється щодня. У період курації викладач знаходиться зі студентами, допомагаючи їм спілкуватися з породіллями, а також контролюючи правильність застосування різних об' єктивних методів обстеження. Найбільші труднощі у студентів виникають при проведенні реанімаційних заходів у новонароджених. У зв' язку з цим, кожен студент відпрацьовує методику проведення АВС-реанімації на манекені, що в подальшому включено в комплексну оцінку при проведенні модульного контролю, а також до переліку практичних навичок при проведенні практично-орієнтованого іспиту на 6 курсі.

При обговоренні результатів курації хворих основний акцент робиться на формування навичок оформлення історії хвороби. Враховуючи багатонаціональний контингент іноземних студентів нашого вузу (навчання здійснюється студентам, які прибули 3 Південно-Східної Азії та Центральної Африки), ведення кожного випадку захворювання обговорюється з урахуванням особливостей регіону, де проживає студент, та організації неонатальної служби країни.

Оцінка кінцевого рівня знань здійснюється у формі рішення ситуаційних завдань. З цією метою розроблені комплекти ситуаційних завдань на паперових носіях за відповідними розділами дисципліни. Зразок ситуаційної задачі для оцінки кінцевого рівня знань студента:

\begin{tabular}{|c|c|}
\hline $\begin{array}{c}\text { № } \\
\text { of } \\
\text { task }\end{array}$ & 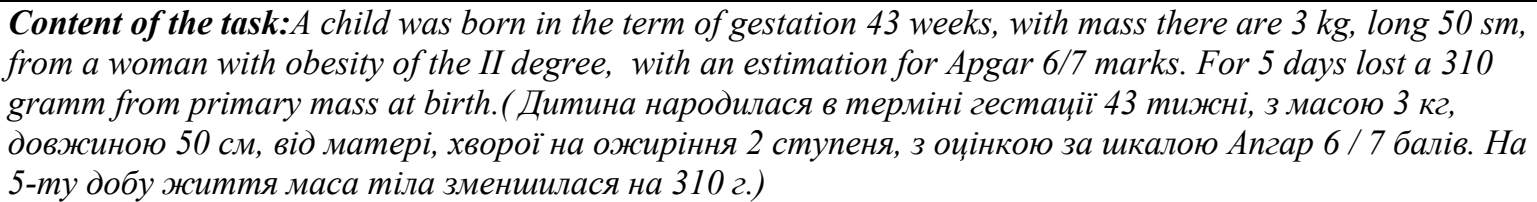 \\
\hline 1 & What does the term of gestation talk about? (Про що свідчить даний те) \\
\hline 2 & To what factors of PFR pathology belongs in mother? (Які фактори перинатальногс \\
\hline 3 & What does this loss of mass talk about?(Про щьо свідчить зниження маси тіла?) \\
\hline
\end{tabular}




\begin{tabular}{|c|l|}
\hline № of task & Standard answer: \\
\hline 1 & Answer: A child is postterm. (Дитина є переношеною.) \\
\hline 2 & To the extragenital risk factors. (Екстрагенітальні фактори ризику.) \\
\hline 3 & About postnatal hypotrophy of I degree. (Про постнатальну гіпотрофію 1 ступеня.) \\
\hline
\end{tabular}

Для інтенсифікації практичного навчання англомовних студентів на кафедрі створені комплексні методичні посібники з усіх тем модуля. До них відносяться методичні розробки для практичних занять, методичні матеріали для самостійної роботи студентів та методичні рекомендації для позааудиторної роботи.

У методичні розробки для практичних занять включені наступні матеріали: актуальність теми, мета i завдання заняття, оновлення базових знань на раніше досліджувані теми і дисципліни, програма самостійної підготовки, алгоритм практичної підготовки студентів, тести та ситуаційні завдання 3 контролю досліджуваного матеріалу, джерела інформації у вигляді списку основної та додаткової літератури.

У методичні розробки з самостійної та позааудиторної роботи включена наступна інформація: мета самостійної роботи, методичні матеріали з самопідготовки, оновлення базових знань $з$ раніше досліджуваних тем і дисциплін, вузлові питання по темі, тести та ситуаційні завдання 3 контролю досліджуваного матеріалу, джерела інформації у вигляді списку основної та додаткової літератури.

Методичні матеріали для студентів щорічно обговорюються на кафедральній нараді і затверджують- ся завідувачем кафедри. Всі матеріали написані англійською мовою і представлені на внутрішньому електронному сайті кафедри. Студенти можуть ними скористатися в електронному читальному залі бібліотеки університету.

Підсумком самостійної роботи є історія хвороби та реферати з основних тем занять. Оцінюються ці види самостійної роботи за бальною системою, що включаються в поточні бали модуля.

Проведений комплекс методичних заходів значно поліпшив “виживання” знань англомовних студентів, що підтверджується результатами модульного контролю та практично-орієнтованого іспиту.

Трирічний досвід кафедри свідчить, що дана система методичного забезпечення дає можливість отримати англомовним студентам достатні знання 3 основних тем неонатології. Вивчення "виживання" цих знань на 6 курсі переконливо підтверджує необхідність впровадження даного комплексного методичного забезпечення викладання на 5 курсі.

Нами був проведений аналіз результатів п'ятирічного державного тестування (КРОК-2) студентів 6 курсу нашого університету з педіатрії (табл. 1 і рис. 4). Згідно з отриманими результатами відзначається

Таблиця 1. Результати державного тестування (КРОК-2) 3 педіатрії студентів 6 курсу Кримського державного медичного університету ім. С. І. Георгієвського

\begin{tabular}{|l|c|c|c|c|c|}
\hline \multirow{2}{*}{ Контингент студентів } & \multicolumn{5}{|c|}{ Правильні відповіді у \% } \\
\cline { 2 - 7 } & 2007 p. & 2008 p. & 2009 p. & 2010 p. & 2011 p. \\
\hline Іноземці англомовні & 79,3 & 83,8 & 83 & 86 & 91 \\
\hline Іноземці російськомовні & 79,1 & 84 & 82,1 & 83 & 92,6 \\
\hline Вітчизняні & 82 & 85,2 & 85,4 & 87 & 98 \\
\hline
\end{tabular}

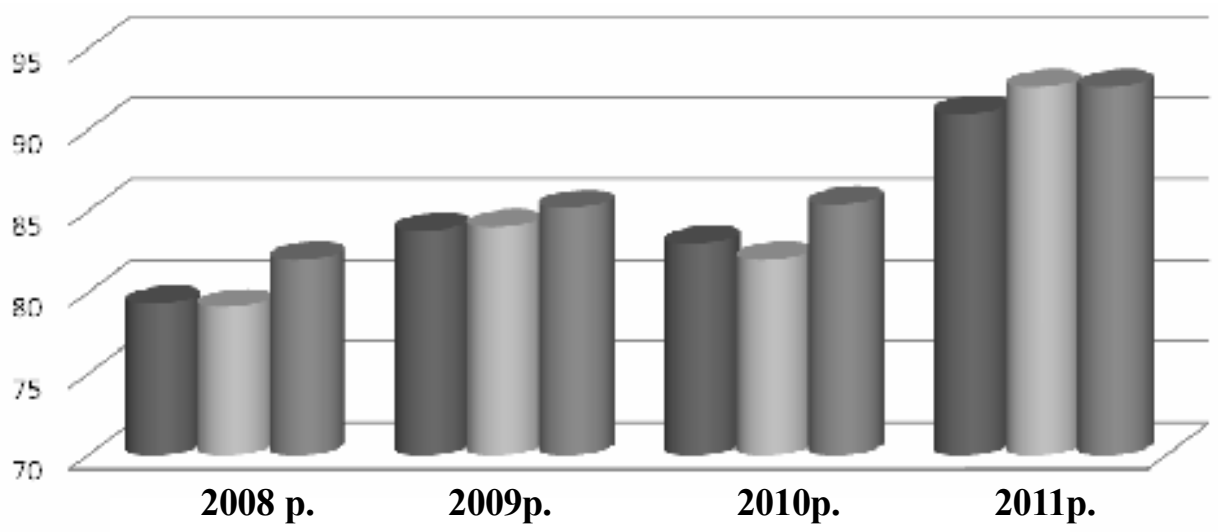

Іноземці англомовні

Іноземці російськомовні

Вітчизняні

Puc. 4. Результати КРОК-2 з педіатрії. 


\section{ВДОСКОНАЛЕННЯ ВИЩОЇ МЕДИЧНОЇ ОСВІТИ}

виражена тенденція підвищення процентного вмісту правильних відповідей при переході на Болонську систему навчання.

Висновки: 1. Викладання неонатології англомовним студентам на 5 курсі відповідно до вимог Болонської системи освіти вимагає комплексного методичного забезпечення.

2. Методика викладання включає в себе як інтен-

\section{Література}

1. Шабалов Н. П. Неонатология : навчальний посібник / Н. П. Шабалов. - [2-ге. вид.]. Т. 1. - СПб. : Специальная литература, 1997. -496 с. сифікацію роботи на практичних заняттях під постійним контролем викладача, так і методичну допомогу в період самостійної та позааудиторної роботи студентів.

3. Результати державного тестування (КРОК-2) переконливо доводять необхідність впровадження комплексного методичного забезпечення при навчанні неонатології англомовних студентів на 5 курсі. 